\title{
TÜRKMEN TÜRKÇESİNDE “hem” BAĞLACININ TİPIK BİR KULLANIMI
}

\section{A TYPICAL USAGE OF THE CONJUNCTION OF "hem" IN TURKMEN TURKISH}

Hüseyin YILDIRIM*

$\ddot{O} z$

Türkmen Türkçesinde "hem" sözcüğ̈̈ bağlaç ve pekiştirici görevinde kullanılır. Bugün yazı dilinde "hem" sözcü̈̆̈̈̈ün " $h$-" ünsüzü düşürülmüş ve damak uyumuna bağlanmış "-am/-em" biçimleri de mevcuttur. Aslında önceleri konuşma dilinde görülen bu kullanım, sonradan yazı diline geçmiştir. İmlâ bakımından hem ya da -am/-em kullanımında belirli bir kural yoktur. Bu ikili kullanımın belirli bir sistemi olmasa da bazı durumlarda bugün standart Türkmen Türkçesinde daha çok-am/-em biçimleri tercih edilir.

Bu makalede örneklerle -am/-em biçiminin yaygın olarak hangi durumlarda kullanıldı̆̆ı, kullanımında ortaya çıkan ses olayları, yalancı eşdeğerliliği, kalıplaşmış tarzda yeni kelimeler türetmesi gibi konular üzerinde durulacaktır.

\section{Anahtar Kelimeler}

Türkmen Türkçesi, bă̆laçlar, "hem" bağlacı, "-am/-em" bağlacı.

\begin{abstract}
In the Turkman Turkish, the word "hem" serves as the conjunction and the expletive. Today in the written language there are also "-am/-em" forms in which the consonant " $h-$ " is deleted in relation with the palatal harmony. In fact, this usage was in the colloquial language in the beginning and passed on to written language afterwards. There is not any specific rule in terms of spelling for the usage of the hem or-am/-em. Although there is not a specific system for this dual usage, in some cases the -am /-em formats are more preferred today in standard Turkmen Turkish.

In this work, examples in which the -am /-em format is commonly used and the subjects such as the sound events, the false equivalence, the lexicalization in a stereotypical manner that occur in use, will be discussed.
\end{abstract}

\section{Keywords}

Turkmen Turkish, the conjunctions, the conjunction "hem", the conjunction"-am/-em".

Yrd. Doç. Dr., Gazi Üniversitesi, Edebiyat Fakültesi, Çă̆daş Türk Lehçeleri ve Edebiyatları Bölümü, Ankaral TÜRKIYE. huseyin@gazi.edu.tr 


\section{Giriş}

Türkmen Türkçesi yazı dilinde bağlaç ve pekiştirici olarak görev yapan "hem", tipik şekilde “-am/-em" biçiminde ekleşmiş ve damak uyumuna bağlanmış olarak da kullanılır.

Türkmen Türkçesi üzerine yazılmış gramerlerde "hem"den gelişmiş "-am/-em" biçiminin kullanımı üzerinde sadece genel bilgiler ve sınırlı örnekler verilmiştir. Mesela, Türkmen Türkçesinin kapsamlı bir grameri olan "Türkmen Diliniň Gramatikası: Morfologiya" adlı çalışmada "hem" in bağlaç olarak (Borcakov vd. 2000: 516) ve hem ya da -am/em şeklinde ovnuk bölek "pekiştirici" olarak (Borcakov vd. 2000: 542) kullanıldığı birkaç örnekle gösterilmiş, ancak hangi durumlarda kullanıldığı, ortaya çıan ses olayları vb. üzerinde detaylı durulmamıştır.

Yazı dilinde "hem"in esas olarak dört kullanım şekli vardır: 1. hem; 2. hem ... hem ...; 3. hem-e ... hem-de ...; 4. hem-de. Mesela:

1. hem = Näçe kyn hem bolsa şeytdi. "Ne kadar zor da olsa yaptı." (BP: 164).

2. hem ... hem ... = Eneli-ogul ikisi hem nan iýdi hem Aýnany hiç kime duýdurman alyp gaçmak hakynda pikir etdi. "Ana oğul ikisi hem yemek yedi hem Ayna'yı hiç kimseye duyurmadan alıp kaçırmak hususunda konuştular." (Gö: 95).

3. hem-e ... hem-de ... = Ol hem-e özüniñ neneñsi abrayl, işbaşarcak gelindigini, hem-de satmak üçin aylap yören bölek-büçek matadır yağllkların görkezmege gelipdi. "O hem kendisinin ne denli saygın, becerikli bir gelin olduğunu, hem de satmak için dolaştırdığı kumaş ve başörtüsünü göstermeye gelmişti." (On: 144).

4. hem-de = Ol dımdı hem-de basım hoşlaşıp, çıkıp gitdi. "O sustu ve de hemen vedalaşıp, çıkıp gitti." (BP: 249).

Bu bağlaç, tek başına hem olarak "ve, da/de, bile, dahi"; hem ... hem ... ikili kalıbıyla "hem ... hem ...; ...da ...da/ ...de ...de; hem-de olarak "hem de, ve, ayrıca" anlamlarında kullanılır, ayrica pekiştirici görevini üstlenebilir (Çelik Şavk 2003: 101).

Türkmen Türkçesinde hem sözcüğü, "hem... hem..." tarzında yinelemeli kullanımlarda birbirine bağladığı unsurlardan önce de sonra da gelebilir. Bu iki yönlü kullanım, Türkmen Türkçesi için farklı bir özelliktir. Bu sözcük, bağladığı unsurdan önce geldiği durumlarda hem biçimindeyken sonra geldiği durumlarda çoğunlukla -am / -em ve seyrek olarak hem şeklinde kullanılmaktadır (Salan 2011: 1732).

"Hem" bağlacı bağlanacağı unsurun önünde geldiği zaman daima "hem... hem..." biçiminde kullanılır: Olar indi hem göz, hem gulak, hem goragdylar... "Onlar şimdi hem göz, hem gulak, hem (de) koruyucuydular..." (S: 245). Ancak bağlanacağı unsurun ardından geldiğinde bağlacın başındaki "h-" ünsüzü düşer ${ }^{1}$ ve -am/-em biçiminde üzerine geldiği kelimeye bitişik yazılarak kullanılı². Bu kullanımıyla çoğunlukla Türkiye Türkçesindeki "da / de" bağlacının görevini karşılar: Tansam, sazam togtadı. "Dans da, müzik de durdu." (Gö: 111).

Türkmen Türkçesindeki "Ovnuk bölekler" üzerine genel bir çalışma yapan Nergis Biray, "ovnuk bölekler"den birisi olarak "hem"i de değerlendirir. Bu çalışmasında Biray, diğer pekiştirme enklitiklerinin dilin ses özelliklerine genellikle uyduğunu ve hemen hemen hepsinin

Türk lehçelerinde h Ø [Mesela, Azerbaycan Türkçesi: hör-<ör-, hörümcek < örümcek (Kartallığlu, Yıldırım 2007: 182); Gagavuz Türkçesi: enez < henüz, üük< höyük (Özkan 2007: 97) gibi] denkliği görülür. Türkmen Türkçesinde de Arapça ve Farsçadan alınma kelimelerin başında, ortasında ve sonunda bulunan $/ \mathrm{h} /$ 'ler bazı kelimelerde düşer. Örneğin: esse < hisse, köne < köhne "eski", şa < şah "şah, padişah" (Kara 2007: 245).

2 Türkmen Türkçesinde "hem" bağlacının "h-" ünsüzü düşerek ekleşmiş -am/-em biçimi her zaman önündeki kelimeye bitişik yazılır; "hem” şeklinde kullanıldığında ise önündeki kelimeden her zaman ayrı yazılır. Kelimelere doğrudan "hem" şeklinde eklendiği görülmez. 
kelimeye ekleşerek kullanıldığını belirtir. Ama "hem"in genellikle kelimeden ayrı yazıldığını bazen de ekleştiğini gösterir: hem; hem >-am, -em. (Biray 2015a: 989).

"Hem" bağlacı işlevleri bakımından da çeşitlilik gösterir. Erkan Salan "hem" sözcügünün Türkmen ve Türkiye Türkçesindeki işlevlerini incelediği yazısında, "hem" sözcügünün bağlaç ve bağlama edatı olarak kullanıldığında "ve", "hem ... hem ..."ve "ama" işlevlerinde olduğunu örneklerle gösterir. hem sözcügünün kuvvetlendirme edatı olarak kullanımında ise "de / da", "bile, dahi", "ayrıca, üstelik, bir de", "olarak" ve "ise" işlevlerinde kullanıldığını örneklerle gösterir ${ }^{3}$ (Salan 2011: 1729-1738).

"Hem" bağlacının -am/-em şeklindeki kullanımının belli bir sistemi yoktur. Kullanıcının tasarrufuna bağlıdır. A. Geldimıradov, "Türkmen Edebi Dilinde Variantlaşma" adlı çalışmasında "birçok durumda gereksiz yere imlâyı bozmanın hiçbir yönden faydası yok", der ve şu yerine şü, $b u$ yerine $b \ddot{u}, b i$; ont-ha yerine on-a, özi-he yerine öz-ä, Amanı hem yerine Amanam, Saparı hem yerine Saparam, geldi-ov yerine geld-ov vb. şeklinde kelime sonundaki seslerin düşürülmesini eleştirir. Gerekçe olarak da "bu şekilde söyleniyor diye böyle yazmanın gereği yok" uyarısında bulunur (Geldimıradov 1983: 57). Diğer bir ifadeyle burada konumuz olan hem bağlacının da $-a m /$-em şeklinde varyantlaştırılmasının imla bakımından yanlış olduğunu ifade eder.

Lary Clark, Türkmen Türkçesinin konuşma dilinde "hem" bağlacının genellikle başındaki "h-" ünsüzü olmaksızın kullanıldığını ve yazı dilinde bazen de -am/-em biçimiyle geldiği kelimeden sonra bitişik yazıldığını belirtir (Clark 1998: 435).

"Hem" aslında hem bağlaç olarak hem de pekiştirici (ovnuk bölek) görevinde kullanılabilir. "Hem" bağlacının ekleşmiş ve men hem yerine menem örneğindeki kullanımında-am/-em biçimi esasen pekiştirici görevindedir.

Türkmen Türkçesinde "hem"in üzerine - $d a$, -de pekiştiricisini almış "hem-de" biçiminde kullanımı da mevcuttur. Şayet "hem" üzerine $-d a$, $-d e$ almışsa bu durumda bağlaç görevinde kullanılır. Pekiştirici görevinde kullanıldığında ise $-d a$, $-d e$ pekiştiricisini üzerine almaz (Pirliyev vd. 1996: 108-109).

"Hem" ya da "-am/-em" tercihinin tarihî sürecine bakacak olursak, -am/-em biçiminin son dönemlerde gittikçe yaygınlaştığı görülür. Bu gelişim süreci metinlerden de takip edilebilir. Mesela, Türkmen Türkçesinin klasik döneminde sen şahıs zamiri "hem” ile kullanılır. Örneğin, Mahtumkulu Divânında sen hem (Biray 1992: 114), Zelilî Divânında sen hem (Yıldırım 2008: XLIV-18) biçimindedir.

Berdi Kerbabayev'in 1929-1956 yılları arasında yazdığı hikâyelerinden seçmelerin bulunduğu "Saylanan Eserler" adlı esere baktığımızda men hem kullanımının 19 defa (SE: 40, 42, $45,45,45,45,49,116,137,216,219,222,267,268,277,302,316$, 316, 327) geçtiği, buna karşl1ık menem kullanımının ise 5 defa (SE: 59, 142, 149, 233, 285) tercih edildiği görülür. Aynı şekilde sen hem kullanımı 5 defa (SE: 40, 46, 104, 309, 3139, senem kullanımı ise 6 defa (56, 174, 265, 181, 279, 184) geçer.

Ancak, Çarı Aşır'ın 1989 yılında yayımlanan "Göreş" adlı eserinde men hem kullanımına hiç rastlanmazken menem kullanımı 23 defa (Gö: 11, 14, 16, 18, 32, 51, 64, 78, 94, 95, 116, 122, 122, 126, 130, 153, 158, 185, 188, 210, 216, 220, 226) geçer. Aynı şekilde sen hem kullanımı hiç görülmezken senem kullanımı 19 defa (Gö: 8, 14, 20, 30, 64, 65, 71, 71, 130, 140, 157, 157, 189, 196, 196, 208, 209, 214, 225) geçmektedir. 2010 yllında yayımlanan Cumageldi Mülkiyev'in

3 Biz bu çalışmada "hem" bağlacından gelişen ve gramatikalleşen -am/-em biçiminin ortaya çıkışı, kullanım sıklığı, yaygın olarak hangi durumlarda kullanıldığı, meydana gelen ses olayları, yalancı eşdeğerlilik gibi hususları değerlendirdik. "Hem" bağlacının Türkmen Türkçesindeki işlevlerine değinmiyoruz. "Hem"in Türkmen Türkçesindeki işlevleri ve Türkiye Türkçesindeki karşılıkları konusunda bkz: Salan 2011. 
"Selcuklar" romanında da men hem ve sen hem hiç geçmezken menem 4 defa $(120,136,165,165)$; senem 1 defa (164) geçmiştir.

Bu verilen örneklerden hareketle günümüzde artık -am/-em tercihinin gittikçe yaygınlaştığı söylenebilir. Diğer bir ifadeyle sadece konuşma dilinde var olan biçim, her ne kadar önceleri eleştirilse de, zamanla yazı diline de geçmiş ve gramatikalleşmiştir.

Aşağıdaki inceleme bölümünde -am/-em biçiminin yaygın olan kullanım yerleri üzerinde durulacaktır.

\section{İnceleme}

"Hem" bağlacının -am/-em biçimi esas olarak isim ve isim türünden kelimelerden sonra gelir. İsim türünden kelimelerden zamirler, zarflar, edatlar ve bağlaçlarla oldukça sık kullanılır. Sayı isimleriyle kullanımı da dikkat çekicidir. Aynı şekilde "-am/-em" biçiminin isim çekim eklerinden ve fiil çekim eklerinden sonra da kullanımının yaygın olduğu görülür.

Türkmen Türkçesinde -am/-em biçiminin kullanımı neticesinde ünlü düşmesi ve tonlulaşma gibi ses olayları da meydana gelir. Ayrıca bazı durumlarda, sen hem > senem "sen de", seni hem > senem "seni de" kullanımlarında olduğu gibi, yalancı eşdeğerlilikler ortaya çıkar. Zarf, edat ve bağlaçlarla yaygın kullanımı sonucunda kalıplaşmış olarak eysem < eyle ise hem "o hâlde", yogsam < yok ise hem "değilse, yoksa" gibi yeni kelime türer ve tipik biçimde bir nevi yapım eki özelliği kazanır.

Aşağıda bağlacın bahsedilen tipik kullanımları; kullanımda ortaya çıkan ses olayları; yalancı eşdeğerlilik gibi hususlar roman ve hikâyelerden taranan örneklerle değerlendirilecektir.

\section{a. İsimlerle Kullanımi ${ }^{4}$.}

"Hem" sözcügünün "h-" ünsüzü düşmüş ve "-am/-em" şeklindeki varyantlaşmış biçimi isim kök ve gövdelerine doğrudan gelebilir.

Men sana öñem aydıpdım. "Ben sana önce de söylemiştim." (SE: 19).

Yol boş, garavulam, hiç kimem yok. "Yol boş, bekçi de, herhangi biri de yok." (Gö: 173).

- Hiç zadam bolanok. "- Hiçbir şey de olmuyor". (SE: 32).

Soltansöyün munuñ üçin saña gara pulam bermez. "Sultansöyün bunun için sana delikli para da vermez." (SE: 296).

- Öz obañıda şonuñ yal gepem yokmı indi... "- Köyünüzde bu tür bir söz de yok mu şimdi..." (S: 223).

Kınam, agıram bolsa, yıllar gelip-geçip dur. "Zor da, ağır da olsa yıllar gelip geçiyor." (Ä: 62).

Ertirem ir turmalısiñ. "Sabah da erken kalkmalısın." (苂: 241).

Bayam bu işe özi razı bolup. "Bey de bu işe razı olmuş."(İkbal: 53).

Hiç vagtam sana artık salgıt salnan däldir. "Hiçbir zaman senden fazla vergi de talep edilmiş de değildir." (Gül:34).

\section{b. Şahıs Zamirleri İle Kullanımı}

Yukarıda da belirtildiği üzere "hem" bağlacının şahıs zamirleri ile kullanımında artık çoğunlukla ekleşmiş biçimler tercih edilir: menem (< men hem), senem (<sen hem), olam ( $<$ ol hem), bizem (< biz hem), sizem (< siz hem), olaram $(<\text { olar hem })^{5}$.

4 Çalışma, "hem"in "-am/-em" şeklindeki kullanımı üzerine olduğu için, taranan metinlerden tespit edilen ve inceleme bölümünde verilen örnekler "-am/-em" biçiminin kullanım örnekleriyle sınırlandırılmıștır. Ancak her ne kadar "hem"e kıyasla "-am/-em" biçiminin kullanımı Türkmen Türkçesinde gittikçe artsa da "hem" kullanımı da devam etmektedir. Mesela: süri hem "sürü de" (S: 21) ya da keyik sürüsi hem "geyik sürüsü de" (S: 21) şeklindeki kullanımlar, kullanıcının tasarrufuna bağlı olarak sürem, keyik sürüsem biçiminde de kullanılabilir. 
$\underline{\text { menem: }}$

Menem seniň gapdalıñda öy tutunarın. "Ben de yakınında ev tutarım.” (BP: 181).

- Ol gürrüñler-ä menem eşitdim. Gızıñ özem, kakasam bize gövneyär. "- O konuşmaları ben de işittim. Kız da, babası da bize rıza gösteriyor." (Gö: 226).

senem:

- Senem şu yerdecik galay! - diyipdir-de, direge baglapdır. "- Sen de burada kal, demiş ve direğe bağlamış." (SE: 279).

olam:

Olam şol medresede okap, yigit çıkdı. "O da bu medresede okuyup, delikanlı oldu." (İkbal: 143).

Olam maña cogap yazdı. "O da bana cevap yazdı." (Gö: 93).

bizem:

Bizem ayaguçda otırıs. "Biz de ayakucunda otururuz.” (Ä: 73).

Seniñ bu günäñi bizem, nesillerimizem geçmez... "Senin bu günahını biz de, nesillerimiz de affetmez..." (S: 34).

İliñ oñan yerinde bizem oñarıs. "Halk gün gördüğünde biz de gün görürüz." (Gül: 10).

sizem:

- Hiyh!...Sizem ogrı şärigimidiñiz? “- Peki!... Siz de hırsızın ortağı mıydınız?” (SE: 151).

olaram:

Olaram pälvan sıpat adamlardı. "Onlar da pehlivan görünüşlü adamlardı." (Gö: 17).

Olaram vagtların biderek geçirip yören däldirler diyip düşünyärdi. "Onlar da vakitlerini boşa

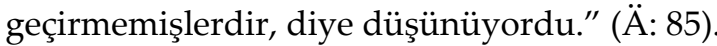

Verilen örneklerde de görüldüğü üzere şahıs zamirlerine "hem” bağlacı artık çoğunlukla am/-em biçiminde gelmektedir. Örneğin, taranan eserlerden "Göreş" romanında men hem, sen hem, olar hem vs. kullanımları hiç yoktur. Sadece iki yerde (sy. 62) ol hem kullanımı tespit edilmiştir:

Sähel zat üçin ol hem meni uryar."Küçük şeyler için o da bana vurur." (Gö: 62).

Şahıs zamirlerinin hâl eklerini almış biçimlerinden sonra "hem" geldiğinde de yine çoğunlukla -am/-em biçimleri tercih edilir ve bitişik yazılır. Özellikle de ilgi hâli ekinden sonra kullanımı oldukça sıktır: meniñem (< meniñ hem), seniñem (< seniñ hem), onuñam (< onuñ hem), biziñem (< biziñ hem), siziñem (< siziñ hem), olarıñam (< olarıñ hem).

Meniñem oglum, agtıcaklarım gitdi. "Benim de oğlum, torunlarım gitti."(Gö: 42).

Olarıñam häzirlikçe edip baryan kömegi yok. "Onların da şu ana kadar yaptığı yardım yok." (Gö:126).

- Gelnece, seniñem işden doyarın̆ yok. "- Yenge, senin de işten usanacağın yok." (Gül: 301).

Paylaşıkda onuñam, meniñem suvumızı artdırdılar. "Paylaşmada onun da, benim de su kullanım hakkımızı arttırdılar."(Gö:152).

Çıkma hâli ekinden sonra da gelebilir:

Käbir batır yigitler kiçicik toparlar bolup, ondanam añrık gitdiler. "Bazı cesur delikanlılar küçük gruplar kurup, oradan daha ileriye gittiler. (GB: 34).

Yükleme hâli eki almış zamirlerden sonra da -am/-em biçimi gelebilir. Bu kullanımda yükleme hâli ekinin ünlüsü düşer ve menem (< meni hem), senem (< seni hem), onam (< onı hem), bizem (< bizi hem), sizem (< sizi hem), olaram (< oları hem) biçimlerinde kullanılır:

Salan "hem" sözcüğünün asıl işlevinin da/de kuvvetlendirme edatı olduğunu bu durumda da "hem"in “h-" ünsüzü düşmüş "-am/-em" biçiminin kullanımının çoğunlukla kişi zamirlerinden, bazı edatlardan (soñ, yaly, üçin vb), bazı zarflardan (dogrudan, heniz, ön vb) vb. sonra ortaya çıktığını belirtir (Salan 2011: 1734). 
- Üç gızım boldı. Biri bar, ikisi öldi. Ol gızımam bay satıp goyberdi. İndi onam görüp bilemok. "Üç kızım oldu. Biri sağ, ikisi öldü. O kızımı da ağa sattı. Şimdi onu da göremiyorum." (Gö: 65).

İlgi hâli eki ve üzerine aitlik eki almış şahıs zamirlerinden sonra da kullanılır:

- Amanin gulagam, meniñkem edil agzı gözelen horcun yalı. "-Aman'ın kulağı da benimki de tıpkı ağzı bağlanmış heybe gibi." (SE: 50).

Biziñkem näme, bir yumşoglanı yall, onuñ habarmı size, siziñkini oña eltip bermek. "Bizimki de ne ki, bir görevli gibi, onun haberini size, sizinkini ona getirip götürmek." (İkbal: 83).

\section{c. Dönüşlülük Zamirleri İle Kullanımı}

"hem" bağlacının dönüşlülük zamirleri ile kullanımında artık çoğunlukla ekleşmiş biçimler tercih edilir: özümem (< özüm hem), özüñem (< özüñ hem), özem (< özi hem), özümizem (< özümiz hem), özüñizem (< özüñiz hem), özlerem (< özleri hem).

\section{özümem:}

Men onuñ bilen gepleşerin, özümem her gün aylanar durarın. "Ben onunla konuşurum, özellikle de her gün dolaşırım." (Gö: 69).

- Meniñ özümem bu mıhmaniñ beyle pälvandıgını bilmedim. "Ben de bu misafirin böyle bir pehlivan olduğunu anlamadım." (Gö: 30).

özüñem:

Sen munı özzïñem bilyän dälsiñ. "Bunu sen de bilmiyorsun.” (BP: 153).

Inha, özüñem görersiñ, ol seni hiç zada zar etmez. "İşte kendin de göreceksin, o seni hiçbir şeye

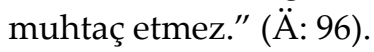

özem:

Özem uzın bolmaga çemeli. “O da uzun boylu sayılabilirdi.”(Gö: 17).

özümizem:

Oña-da razı bolman, özümizem gözetledik. "Bununla da yetinmeyip, biz de aradık." (Gö: 215). özüñizem:

Şükür, özüñizem gurgun oturanmısiñz? "Şükür, kendiniz de (siz de) iyi misiniz?" (Gül: 5).

özlerem:

Özlerem gatı pälvan adamlar. "Onlar da çok güçlü kişiler." (Gö: 16).

Dönüşlülük zamirlerinin hâl eklerinden özellikle ilgi hâli ve yükleme hâli eki almış biçimlerinden sonra da -am/-em biçimi kullanılır:

Özümiñem, ähli doganlarımiñam çagaları aç otırlar. "Benim de, tüm kardeşlerimin de çocukları açlar." (Gö: 39).

Özüñem, olaram goracak sen. "Kendini de, onları da koruyacak sensin.” (Gö: 209).

- ... senin özüñem (özüñi hem) yere sokarın!.. "- ... seni de yere sokarım.” (SE: 56).

Ol göçüñ çöle çekilenini, özüniñem Sarahsa ugranını habar beryärdi. "O göç kervanının çöle çekildiğini, kendisinin de Sarahsa'ya yöneldiğini haber etti." (S: 63).

Özünem köp vagtlap ızına adam saldık. “Onu da çok bekleyip peşine adam saldık.” (Gö:215).

\section{ç. İşaret Zamirleri İle Kullanımı}

Şahıs zamirlerinde olduğu gibi bu / bular, şu / şular, ol / olar, şol / şolar işaret zamirleri ile kullanıldığında da çoğunlukla ekleşmiş biçimler gelir:

Şol divana Bekmırat bay hem çagırılya, munam eşitdim. "Bu meclise Bekmırat Bey de çağrılıyor, bunu da işittim." (İkbal: 280).

Mundanam yigrimi sanısı seniñki. "Bunlardan da yirmisi senin." (苂: 95).

Munuñam köp sebäbi bardl. "Bunun da çok sebebi vardı." (Gül: 50).

Birden bularam (bular hem) yol bozup Hindistana hiyallanaysalar. "Aniden bunlar da yol değiştirip Hindistan'a yönelirlerse." (S: 136). 


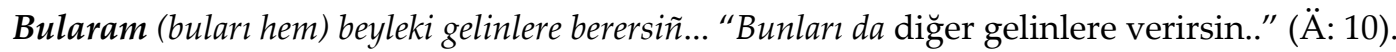

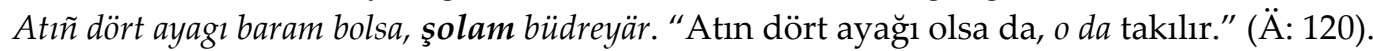
Şonam pikir etmeli. “Bunu da düşünmeli." (İkbal: 231).

Şonam bilyänmi? "Onu da biliyor musun?" (Gül: 9).

Şonuñam iñ yaman seniñ edyän govı işiñi tersine çövrüp, mañlayıña uryanıdır. "Bunun da en

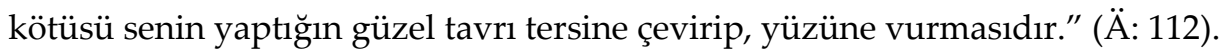

Çagalar okuva yedi yaşını doldurıp ya-da şondanam soñ gelyärler. "Çocuklar okula yedi yaşını doldurup ya da yedi yaşından sonra başlarlar." (苂: 148).

\section{d. Sayılardan Sonra Kullanımı}

Sayılarla kullanımı da oldukça yaygındır.

Zeñ̃ni hacıbıñ müñ tüyüniñ birem gımıldamadı. "Zenci elçinin kılı bile kıpırdamadı." (SE: 151).

Serkerdeleriñ ikisem şol niyetdedi. "Komutanların ikisi de bu niyetteydi."(S: 237).

İkisiniñem gızı yokdı, bassaş-bassaşca ogulları bardı. "İkisinin de kızı yoktu, yaşıt oğulları vardı."(Gö: 50).

Olariñ üçüsiniñem birden Nazara gözi düşdi. “Onların ü̧̈ünün de birden Nazar'a gözü ilişti.” (Gö: 31).

Yedi doganiñ yedisem Akmırat bayıñ dayhançılıgını edyärdi. "Yedi kardeşin yedisi de Akmırat beyin çiftçiliğini yapıyordu." (Gö: 1).

Yedi ogluniñ yedisinem öyli-işikli edipdi. "Yedi oğlunun yedisini de evlendirmişti." (Gö: 1).

Entek yer - yurtsuz vagtları bir bölek atla baş bolup Anadolı taraplara barlag yörişlerini gurap yören dövürleri Çagrı beg otuzam yaşamandı ahırı... "Yersiz yurtsuz zamanlarında bir bölük atla Anadolu taraflarına düzenledikleri keşif seferleri sırasında Çağrı Bey henüz otuz yaşında bile değildi." (S: 121).

\section{e. İsim Çekim Eklerinden Sonra Kullanımı}

İsimlere doğrudan gelebildiği gibi, isimlerin çekim eki almış biçimlerinden sonra da gelebilir ve kullanımı oldukça yaygındır.

Çokluk Ekinden Sonra

- Ene ay ene! Şol vagtda mekdeplerem garañkımıdı? “- Nine ey nine! O zaman okullar da karanlık miydı?" (SE: 58).

Bu gızlaram barıp yerleşdiler. "Bu kızlar da gidip yerleştiler." (Gö: 109).

Iyelik Eklerinden Sonra

Teklik 1. Sahısla Kullanımı:

Akmırat kakamam bir zat diyse diyip oturıberyär. "Babam Akmırat da bir şey dese, deyip duruyor." (Gö: 177).

-Meniñ eşegimem yok, yükümem... “- Benim eşeğim de yok, yüküm de...” (S: 74).

Ecemem gatı görer. "Annem de kızar." (BP: 127).

Teklik 2. Șahısla Kullanımı:

- Agalariñam, gelneceleriñem barı gurgun! "Ağabeylerin de, yengelerin de hepsi iyi!" (Gö: 93).

- Begenç molla, seniñ o diyeniñem bolmaz. "- Begenç molla, senin o söylediğin de olmaz." (Gö: 77).

Teklik 3. Sahısla Kullanımı:

Onuñ ayalam meni uryar. "Onun hanımı da beni döver." (Gö: 62).

- Bay aga, munuñ kellesem yok, şaham yokla! "Beyim, bunun başı da yok, boynuzu da yok ya!" (SE: 191).

Çokluk 1. Șahısla Kullanımı: 
Obadaşlarımızam sizden hoşal bolarlar, hızmat ederler. "Köylülerimiz de sizden memnun

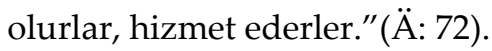

Öçlülerimizem gan alman dınmaz. "Hasımlarımız da intikam almadan durmaz." (Gö: 35).

Çokluk 2. Șahısla Kullanımı:

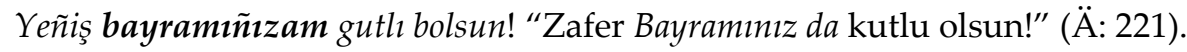

Eneñiz-atañızam tanılgısız adamlar. "Nineniz dedeniz de tanınmadık kişiler." (Gül: 43).

Çokluk 3. Șahısla Kullanımı:

Ine, suv nobatlaram yetip geldi. “İşte, (onların) su straları da geldi.” (Gö: 2).

Hâl Eklerinden Sonra

Özellikle ilgi hâli eki almış isimlerden sonra sık kullanılır:

Ol yedi doganiñam adından dileg edyärdi. "O yedi kardeş adına da dilek tuttu." (Gö: 44).

Doganlarımiñam Hıva giden kireyi vagtında berlip durulsa, olaram aç bolmazdı. "Kardeşlerimin de Hive'ye giden kirası zamanında verilse, onlar da aç kalmazdı." (Gö: 34).

Bäşimiñem, Altınıñam çagaları kändi. "Bäşim'in de, Altın'ın da çocukları çoktu." (Gö: 10).

Hovliniñam yekece gapısı bar. "Avlunun da tek kapisı var." (Gö: 93).

Bu gice olarĩ ikisiniñem gözlerine ukı gelmedi. "Bu gece onların ikisinin de gözlerine uyku girmedi." (BP: 203).

- Sen bu keselden gutulañok, tebibiñem, işanıñam saña peydası yok. "Sen bu hastalıktan kurtulamazsın, doktorun da, üfürükçünün de faydası yok." (Gö: 131).

Çıkma hâli eki almış isimlerden sonra kullanımı da sıktır:

- Men-ä hiç yerdenem gelemok. “- Ben mi, hiçbir yerden gelmiyorum.” (SE: 113).

Bäşimiñ ayah öñküdenem gatı aglap başladı. "Bäşim'in hanımı öncekinden de fazla ağlamaya başladı." (Gö: 54).

Bu pikir öñdenem soltaniñ kellesinde bardı. "Bu fikir önceden de sultanın kafasında vardı." (S: 238).

Yönelme ve bulunma hâli gibi geniş ünlülü ya da son sesi geniş ünlülü olan eklerden sonra ise "hem"den ziyade çoğunlukla -da / -de pekiştiricisi tercih edilir:

- Aýratyn hüjräni näme etjek, oglum, öý gin ahyry, ýaşamaga-da, namaz okamaga-da ýer ýeterlik ýaly-la... "-Ayrı odayı ne yapacaksın, oğlum, ev geniş, yaşamaya da, namaz kılmaya da yeteri kadar mekân var neticede.." (S: 15).

- Şu yerde-de müñ tılla bar... "Burada da bin altın var..." (S: 119).

Goyunlariñ öñünde-de ot yok. "Koyunların önünde de ot yok." (Gö: 97).

Çöl, sagda-da çöl, çepde-de... "Çöl, să̆da da çöl, solda da..." (S: 249).

\section{Aitlik Ekinden Sonra}

Bu kullanımında aitlik ekinin ünlüsü düşer.

- Äy. Nazarıñkam dogrı - diyip, başlık Hangula seretdi. “Müdür: -Eee. Nazar'ınki de doğru diyerek Hangulı'ya baktı." (Gö:199).

Meniñkem yele giden söz bolar-da. "Benimki de havaya giden söz olur." (İkbal: 337).

Seniñkem hut şeyle bolar... "Seninki de tıpkı böyle olur..." (On: 37).

\section{f. Fiil Çekim Eklerinden Sonra Kullanımı}

- Ey soltanım, siz Mıralın näçe sınlasañızam, siz onı entek tanap bileñzok. "- Ey sultanım, siz Mıralı'ya ne kadar baksanız da, şu an onu tanıyamazsınız." (SE: 327).

Bir tabak yaglı govurman gördümem etmedi. "Bir tabak yağlı kavurma dişinin kovuğunu bile doldurmad.." (Gö:14). 
Duydansız bir bakışda mahmalı yüzüne çekdem, şol halatda meniñ akılımı başımdan aldı. "Ani bir hareketle örtüyü yüzüne çekti de, bu hâlde bile benim aklımı başımdan aldı. (İkbal: 129).

- Acal kastiña çıksa, nirede bolsañam tapar. "- Ecel isterse, nerede olsan ol bulur." (GB: 12).

- Sen elli yaşasañam, meniñ üçin çagasiñ, oğlum. "Sen elli yaşında olsan da, benim için

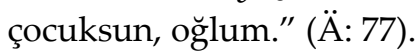

Men hiç bir bazarda alamogam, satamogam. "Benim hiçbir pazarda aldığım da yok, sattığım da." (İkbal: 294).

- ... onda men-ä sizin yaniñzda durcagam däl. “... o zaman sizin yanınızda duracak da değilim." (SE: 158).

- Ahırı bir gün bilmelem-ä bolarlar. Nice sarı on gizläp saklacak? “- Sonunda bir gün öğrenecekler ya. Ne zamana kadar onu gizleyip saklayacak?" (Gül: 297).

\section{g. Fiilimsilerden Sonra Kullanımı}

Sıfat-fiil, zarf-fiil ve isim-fiil eklerinden sonra da gelebilir:

Bilezigi görenem, tapanam, alanam men. "Bileziği gören de, bulan da, alan da benim." (BP: 113).

Bu yerde utcak bolyanam çöldi. "Burada kazanacak olan da çöldü." (S: 249).

İsleseñiz, olardan bir näçesini okabam bereyin. "İsterseniz, onlardan bir kaçını da okuyuvereyim." (SE: 26).

Dölede peç oturtmagam bolcak däl. "Ahıra soba kurmak da mümkün değil." (Gö: 69).

Hun tölemegem añsat zat däldir. "Kan hakkı ödemek de kolay şey değildir." (Gö: 44).

\section{g. Ortaya Çıkan Ses Olayları}

Kök hâldeki ya da çekimli kelimelere geldiğinde ünlü düşmesi ve tonlulaşma gibi ses olaylarına sebep olur.

\section{Ünlü Düşmeleri}

Orta Hece Ünlüsü Düşer

"-am/-em biçiminin kullanımında ortaya çıkan en tipik ses olayı ünlü düşmeleridir. Önce "hem" sözcügünün "h-" ünsüzü düşer ve kök ya da gövde hâlindeki isimlere doğrudan -am/-em biçimi gelir. Sonra da -am/-em biçiminin eklendiği kök ya da gövdenin orta hecesinde bulunan dar ünlü vurgusuz hecede kalarak düşer. Mesela, demir hem > demirem > demrem; agız hem > agızam > agzam gibi:

Hey demrem (< demir hem) iyip bomı? "Hey demir de yenir mi?" (SE: 19).

Yöne Italmaziñ gelşi hakda bir agzam (<agız hem) sözlemedi. "Ancak İtalmaz'ın gelişi hakkında bir tek söz bile söylemedi." (Gö: 31).

- Dünyä-de dünyädir velin, altın-kümşem (< kümüş hem) yatdan çıkarma! "- Dünya dünyadır ama altın gümüşü de hatırdan çıartma!" (苂: 10).

- Bolyar-da, geziber, tomsam (< tomus hem) tiz geçer. "- Peki tamam, geziver, yaz da çabuk geçer." (Gö: 187).

Gör, näçe vagt geçdi. Yöne seysem (< seyis hem) görnenok, yaşulam gara berenok, yaş yigidem. "Bak, nice vakit geçti. Ancak seyis de görünmüyor, ihtiyar da belirmedi, genç delikanlı da." (Ä: 27).

\section{Üzerine Geldiği İsmin Son Ünlüsü Düşer}

"Hem” sözcüğünün "h-" ünsüzü düşmüş ve gramatikalleşmiş “-am/-em” biçimi esas olarak ünsüzle ya da dar ünlü ile biten köklerden veya çekimli kelimelerden sonra gelir; geniş ünlü ile bitenlerden sonra gelmez. Diğer bir ifadeyle Türkmen Türkçesinde geniş ünlülü kelimelerden sonra "hem" bağlacının "-am/-em" biçimini kullanılmaz. Son sesi geniş ünlü ile bitenlerden 
sonra pekiştirme görevinde ya doğrudan "hem" ya da daha çok -da/-de başta olmak üzere diğer pekiştiriciler kullanılır.

Dar ünlülü kök ya da çekimli kelimelerin üzerine -am/-em geldiğinde, kelimenin sonundaki dar ünlü düşer. Mesela, yagşı hem > yagşı+am > yagşam; ecesi hem > ecesi+em > ecesem gibi.

Burada bu düşme sürecinin, önce "hem" sözcügündeki "h-" ünsüzünün düşmesi, daha sonra kök ya da çekimli kelimelerin sonunda bulunan "-1, -i" dar ünlüler ile -am/-em şekline gelen sözcügün ünlülerinin birleşip diftong oluşturması ve en sonunda da dar ünlülerin düşmesi şeklinde bir gelişim gösterdiği kabul edilebilir. Ancak neticede Türkmen Türkçesinde iki ünlü yan yana geldiğinde ikincil uzunluklar ortaya çıkarken "-am/-em" biçiminin ünlülerden sonraki kullanımında uzunluk ortaya çıkmaz. Şayet uzunluk ortaya çıkmış olsaydı ekleşmiş “-am/-em" varyantlarındaki ünlüler uzun olurdu ve /e/6 yerine /ä/ şeklinde yazılırdı.

Dar ünlülü köklerden sonra geldiğinde dar olan ünlü düşer:

-Yagşam (<yagşı hem) bir dogan ekeniñiz! "- İyi de bir kardeşmişsiniz!" (SE: 202).

Nähilem (< nähili hem) bolsa, biz tapanımızdan hun tölecek bolmalı. "Her nasıl olursa olsun, biz elde ettiklerimizle kan bedeli ödemeliyiz." (Gö: 43).

Bularıñ içinden mugallımam, alımam, yazıcam (< yazıcı hem), artistem çıkar. "Bunların içinden öğretmen de, âlim de, yazar da, sanatçı da çıar." (Gö: 113).

Ol gaygılam (< gaygılı hem) däl, gorkulam (< gorkulı hem) däl... “O kaygılı da değil, korkmuş da değil..." (Gö: 176).

Boyı kiçem (< kiçi hem) bolsa, çaganiñ mertebesi belent. “Boyu küçük de olsa, çocuğun mertebesi

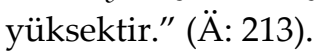

Özem senden gatı ulam (<ulı hem) däl. “O, senden daha büyük de değil.” (Gö: 224).

Yükleme Hâli Eki Düşer

Türkmen Türkçesinde yükleme hâli eki ünsüzle biten isim kök ve gövdelerinden sonra -l/-i, ünlüyle bitenlerden sonra ise $-n l /-n i$ biçimindedir. Yükleme hâli ekinin $-1 /-i$ varyantından sonra "hem" geldiğinde önce bu kelimenin başındaki "h-" ünsüzü ve yükleme hâli ekinin -l/-i varyantı gızı hem > gızam "kızı da", öyi hem > öyem "evi de" örneklerinde olduğu gibi düşer:7

Bu gızam (< gizı hem) zalım bayıñ özi alcakmıka? "Bu kızı da zalim bey alacak mı acaba?" (Gö: 66).

Kakasınam (< kakasını hem), ecesinem (< ecesini hem) alı ötä gitdi. "Babasını da, annesini de alıp öteye gitti." (Gö: 204).

Altınam (< Altını hem), Bäşimem (< Bäşimi hem), Dörtgulın öldürseñizem bolyar. "Altın'ı da, Başim'i de, Dörtgulı'yı öldürseniz de olur." (Gö: 8).

Ol meniñ kakamam (< kakamı hem), ecemem (< ecemi hem) tanayar ahırı. "O benim babamı da, annemi de taniyor neticede." (Gö: 132).

Başlıgam, Novruzam, Oraz aganam, Nazaram, Nenegülem şayat hökmünde suda çagırdılar. "Müdürü de, Novruz'ı da, Oraz beyi de, Nazar'ı da, Nenegül'i de şahit olarak mahkemeye çağırdılar." (Gö: 227).

Türkmen Türkçesinde /e/ ünlüsü birkaç örnek haricinde her zaman kısadır ve uzun biçimde söylenmez. İkincil bir uzunluk ortaya çıktığında /ä/ biçiminde yazılır ve uzun söylenir.

7 Türkmen Türkçesinde iki ünlü üst üste geldiğinde ikincil bir telafi uzunluğu ortaya çıkar. Örneğin ünlü ile biten bir isimden sonra yönelme hâli eki geldiğinde kelimenin son ünlüsü ile $+a /+e$ yönelme hâli eki birleşir ve ikincil uzunluk oluşur: kiçi+e > kiçä (kiçä:) "küçüğe"; Marı+a > Mara (Mara:) "Marı'ya" gibi. Ancak ünlü ile biten kök ya da çekimli kelimelerden sonra -am/-em geldiğinde ikincil uzunluk oluşmaz. Bu durum da, yükleme hâli ekinde olduğu gibi, aslında -am/-em biçiminin üzerine geldiği dar ünlülerin düştügünü gösterir. 
Yükleme hâli ekinin $-n \imath /-n i$ varyantından sonra -am/-em geldiğinde ise bu varyantın sonundaki ünlü, dünyäni hem > dünyänem "dünyayı da", çaganı hem > çaganam "çocuğu da" örneklerinde görüldüğü gibi düşer:

Turkmençänem (< Turkmençäni hem) suv yalı bilyä. "Türkmen Türkçesini de su gibi biliyor." (İkbal: 251).

- Hudaya şükür, o dünyänem (< dünyäni hem) görüp geldim! - diydi. "-Allah'a şükür, o dünyayı da görüp geldim!, dedi." (SE: 213).

Suv üstünde öz doganınam (< doganını hem) öldüryän bar. "Su için öz kardeşini bile öldüren var." (Gö:86).

Ayna yuvaş-yuvaşdan elipbiyem, aydım aytmanam (< aytmanı hem), tans etmänem (< etmäni hem) övrenip başladı. "Ayna yavaş yavaş alfabeyi de, türkü söylemeyi de, dans etmeyi de öğrenmeye başladı." (Gö: 107).

Nökerleriñ iñ soñkusınam (< soñkusını hem) gıllçdan geçiryärler. "Askerlerin en sonuncusunu da k1liçtan geçirirler." (Gö: 173).

Ol häzir Abu Tahırı̃̃ özüne näme diyceginem (< diycegini hem) bilyärdi. "O artık Abu Tahır'ın kendisine ne diyeceğini de biliyordu."(S: 73).

Yükleme hâli eki almış zamirlerden sonra geldiğinde de yükleme hâli ekinin ünlüsü düşer:

Ol bir habar aytcaga meñzeyärdi, onam (< onı hem) aydıp bilmän, yaydanıp durdl. "O bir haber

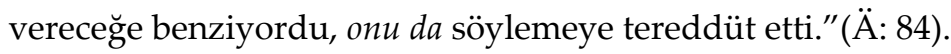

Şonam (< şonı hem) kervene goşaysañ... "Onu da kervana dâhil edersin..." (S: 120).

- Ikimize şonam berseler razı bolaymalıdır. "İkimize bunu da verseler razı olmalı." (Gö: 36).

Iyelik Eki Düşer

Türkmen Türkçesinde teklik ve çokluk 3. şahıs iyelik eki ünsüzle biten isim kök ve gövdelerinden sonra $-1 /-i$, ünlüyle bitenlerden sonra ise -si/-si biçimindedir. Yukarıda yükleme hâli ekinde olduğu gibi, 3. şahıs iyelik eklerinin - $-1 /-i$ varyantından sonra "hem" geldiğinde "h-" ünsüzü ve 3. şahıs iyelik ekinin -l/-i varyantı yeri hem > yerem "(onun) yeri de", malı hem > malam "(onun) malı da" örneklerinde olduğu gibi düşer:

Yöne yeñleri çermelgi, iki omzam (< omzu hem) yırtık. "Ancak kolları katlanmış, iki omzu da yırtık."(Gö: 187).

- Bay aga, munuñ guyrugam (< guyrugı hem) yok-la!“-Beyim, bunun kuyruğu da yok ya!” (SE: 192).

- Dogrı, Nurberdiñ yerem (< yeri hem), suvam (< suvı hem) gitdi. “- Hakikaten, Nurberdi'nin yeri de, suyu da gitti." (Gö: 153).

Nurmiradiñ oglanlaram, oları̃̃ doganoglanlaram (< doganoglanları hem) bu gün suv nobatlar bolanı üçin obadadılar. "Nurmırat'ın oğulları da, onların kardeş çocukları da bugün sulama sıraları olduğu için köydeydiler." (Gö: 5).

Akmıradiñ ayallaram (< ayalları hem), onun ogullaram (<oğulları hem), gelinlerem (<gelinleri hem), Italmazin gelinlerem oña iş buyuryarlar. "Akmırat'ın hanımları da, onun oğulları da, gelinleri de, İtalmaz'in gelinleri de ona iş buyuruyorlar." (Gö: 121).

Ol garıplarıñ malam (< malı hem) yok, iş guralam (< gurah hem). "O garibanların malı da yok, işaletleri de." (Gö: 186).

Garamtıl reñkli balagınıñ dizlaram (< dizları hem) yırtık. "Siyahımsı pantolonunun dizleri de yırtık." (Gö: 187).

Teklik ve çokluk 3. şahıs iyelik eklerinin -l/-i varyantında olduğu gibi, "-am/-em" biçimi -sı/si varyantından sonra geldiğinde de -sl/-si ekinin ünlüsü aynı gelişim sürecini gösterir ve ecesi 
hem > ecesem "(onun) annesi de", babası hem > babasam "(onun) dedesi de" örneklerinde olduğu gibi düşer:

Onuñ kellesem (< kellesi hem) bar yalı-la! "Onun başı da var gibi!” (SE: 283).

Öz babasam (< babası hem) köne arapça yazılan dessanları okap bilyän eken. "Dedesi de eski Arapça yazılmış destanları okuyabiliyormuş." (Gö: 84).

Bu oglanıñ okayşına babasam (< babası hem) begenyär. "Bu oğlanın okumasından dedesi de memnun." (Gö: 74).

Onuñ bilim derecesem (< derecesi hem), soraglara beryän cogaplaram Mercanoviñ gövnüne yaran bolmaga çemeli. "Onun bilim derecesi de, sorulara verdiği cevapları da Mercanov'un gönlüne dokunacak şekildeydi." (Gö: 202).

\section{Fiil Çekim Eklerinin Son Ünlüsü Düşer}

Son sesi dar ünlü olan - $d l /$-di görülen geçmiş zaman eki ve -mall/-meli gereklilik kipi ekinden sonra "hem"den gramatikalleşen "-am/-em" biçimi geldiğinde de, yükleme hâli ve 3. şahıs iyelik ekinden sonra ortaya çıkan gelişim süreci gerçekleşir ve eklerin dar olan son ünlüsü düşer:

Duydansız bir bakışda mahmalı yüzüne çekdem (< çekdi hem), şol halatda meniñ akılımı başımdan aldı. "Ani bir hareketle örtüyü yüzüne çekti de, bu hâlde bile benim aklımı başımdan aldı." (İkbal: 129).

- Ahır bir gün bilmelem-ä (bilmeli hem-ä) bolarlar. Nice sarı on gizläp saklacak? "- Sonunda bir gün öğrenecekler ya. Ne zamana kadar onu gizleyip saklayacak?" (Gül: 297).

\section{Tonlulaşma}

Türkmen Türkçesinde "hem" bağlacının /ç, k, p, t/ tonsuz ünsüzleriyle biten kelimelerden sonra ekleşmiş -am/-em biçiminin gelmesi tonlulaşma olayına da sebep olur ve bu tonsuz ünsüzler /c, g, b, d/ tonlu seslerine döner.

ç>c

Onuñ bilindäki altın ginlı gilıcam (gilıç hem) görnüp başlayar. "Onun belindeki altın kinlı kllıç da görünmeye başlar." (Gö: 172).

Emma yaragsızdılar ahırı, hatda gılıcam (gıllıç hem) billerinde däldi. "Ancak silahsızlardı, hatta kılıç bile bellerinde değildi." (PE: 524)

$\mathrm{k}>\mathrm{g}$

- Şu matadan köynegem, balagam tikseñiz bolar.. “- Bu kumaştan gömlek de, pantolon da dikebilirsiniz.."(Gö: 135).

- Men häzir çöregem getirerin... "-Ben şimdi ekmek de getiririm..."(S: 221).

Yöne, bu pursat çadırıñ içinde uçup yören siñegem yokdı. "Ancak, o esnada çadırın içinde uçan sinek de yoktu." (S: 280).

Seni diñlemegem islämok. "Seni dinlemek de istemiyorum." (BP: 81).

Mugallım yerinde yogam eken-dä, mekdep yerinde dur ahırın. "Ö̈̆retmen yerinde yok da, okul yerinde duruyor neticede." (苂: 117).

$\mathbf{p}>\mathbf{b}$

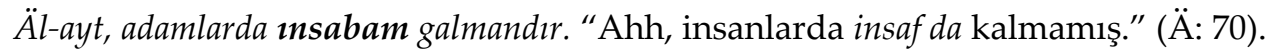

Bu yoldan bayam geçdi, garıbam, garram geçdi, yaşam. "Bu yoldan zengin de geçti, yoksul da, ihtiyar da geçti, genç de."(Gö: 176).

- Tiz vagtda öz dilimizde kitabam bolar, aydımam diydi. "- Tez vakitte kendi dilimizde kitap da olur, şarkı da dedi." (Gö: 117). 
$\mathbf{t}>\mathbf{d}$

Ol yigidem meni gördi öydyän... "O yiğit de beni gördü sanırım..." (Gö: 12).

Şol pursadam yabıñ rayşındakı iki cübüt ayakgaba gözi kaklışdı. "O esnada da kanalın kıyısındaki

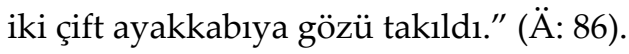

Tonlulaşma ses olaylarından en tipik olanı ise -Ip zarf-fiil ekinden sonraki kullanımıdır. am/-em biçimi zarf-fiil ekinden sonra çok sık gelir ve geldiğinde /p/ ünsüzü tonlulaşarak /b/'ye döner:

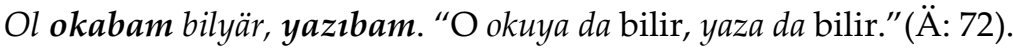

Onı az görübem agılda duran işşekleriñ birini soydurmakçı boldı. "Onu biraz görüp de ağılda

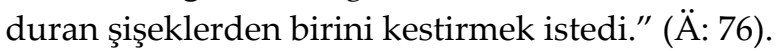

Elbetde, onuñ öyünde-de uklanardam, iylibem-içilerdi. "Elbette, onun evinde uyunurdu da, yenilip içilirdi de." (GB: 5).

- Biz gezibem gördük, göçübem gördük, hiç yerde özümiziñkiden govı yurt görmedik. "-Biz gezip de gördük, göç edip de gördük, hiçbir yerde kendimizinkinden iyi yurt görmedik." (SE: 264).

\section{h. Yalancı Eşdeğerlilik}

Türkmen Türkçesindeki "hem" bağlacının -am/-em biçiminde kullanımının en tipik özelliklerinden biri de kelimelere ekleşmiş şekilde bitişik yazıldığında bazen yalancı eşdeğerliliğe sebep olmasıdır.

Mesela, senem "I. Put; II. Sevgili" (TS 2016: 281) hem müstakil bir kelime hem de sen şahıs zamiri üzerine "hem" bağlacının gelip sen hem > senem gelişimi göstermiş şekil olabilir:

Badam gabak, alma yanak // Bir zıba senem islärin "Badem göz, elma yanak // Bir güzel sevgili isterim" (Mahdumkulu) (TS 2016: 281).

- Bay aga, senem (< sen hem) şolardan. "-Bey, sen de onlardansin." (SE: 147).

Bir başka örnekte bala "evlat, çocuk" sözcüğünün teklik 1. şahıs iyelik eki almış balam şekliyle, bal kelimesinin “-am/em” biçimini almış balam şekli benzeşerek yalancı eşdeğerlilik ortaya çıkar:

- Vah, balam (bala+m), kakañ sana kän garaşandır! "-Ahh, evladım, baban sana çok bakınmiştır." (SE: 125).

- Maña canam gerek, balam (<bal hem). "-Bana can da gerek, bal da." (SE: 281).

Aynı şekilde baş "baş, kişi, birey vs." kelimesinin "hem” bağlacını almış başam biçimi, başam (barmak) "başparmak" kelimesi ile benzeşir ve yalancı eşdeğer olarak karşımıza çıkar:

- Hava, oglanıñ derman eder yalı iç kesel-ä yok - diyip, bir barmagını yumdı. - Melhem eder yalı görnüp duran başam (< baş hem) yok - diyip, ikinci barmagını yumdı. "-Evet, oğlanın tedavi edilebilecek gibi bir iç hastalığı da yok, deyip bir parmağını yumdu. - İlaç yapabilecek gibi görünen kişi de yok, deyip ikinci parmağını yumdu." (SE: 68).

Yay atyan esger sag eliniñ başam barmagını mıdama goramalıdı. "Yay çeken asker sağ elinin özellikle başparmă̆ını daima korumalıydı." (S: 46).

Şu örnekte geçen yaşam (< yaş hem) "genç de" kullanımının Türkiye Türkçesindeki yaşam kelimesi ile bir ilgisi yoktur: - Yaşam bolsa zıyanı yok, gan ucundan alnan duşman çagasıdır. "- Genç de olsa ziyanı yok, kan bedeli karşılığında alınmış düşman çocuğudur." (Gö: 60).

Bazen de ortaya çıkan ses olayları yalancı eşdeğerlilik yaratabilir. Örneğin, Türkmen Türkçesindeki senem kullanımı hem sen zamirinin yalın hâldeki (senem < sen hem) hem de yükleme hâlindeki çekimli şekil üzerine -am/-em almış biçim olabilir (senem < seni hem). Diğer bir ifade ile senem "1. sen de, 2. seni de"; sizem "1. siz de, 2. sizi de" gibi örnekler iki anlama gelen kullanimlardır: 
- Senem (< sen hem) şu yerdecik galay! - diyipdir-de, direge baglapdır. "- Sen de burada kal, demiş ve direğe bağlamış." (SE: 279).

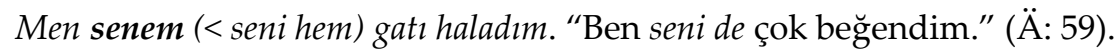

Şonuñ üçin sizem (< siz de) olara bet doga ediñ! "Bu yüzden siz de onlara beddua edin! (Gö: 180).

- Zaman, mollañiz sizem (< sizi hem) uryamı? "- Zaman", mollanız sizi de döver mi?" (SE: $59)^{9}$.

\section{Pekiştirme Fonksiyonuyla Bir Enklitik Olarak Kullanımı}

Giriş bölümünde de belirtildiği üzere "hem" sözcügünün -am / -em biçimi Türkmen Türkçesinde pekiştirme fonksiyonunda da kullanılır. Dikkate değer biçimde -em biçimi hem bağlacının üzerine de gelebilir ve böylece anlamı pekiştirmek için hemem şekli ortaya çıkar:

Bar-da çagaları ogşa, hemem (< hem hem) olara meniñ tiz barcagımı ayt. "Git de çocukları okşa, hem de benim tez geleceğimi söyle." (BP: 203).

- Hem söyyän, hemem... hemem yigrenyän.. "-Hem seviyorsun, hem de... hem de nefret ediyorsun.." (BP:179).

Yöne yüzünde biricigem yıgırt yokdı. "Ancak yüzünde bir tane bile kırışı yoktu." (BP: 11).

Men han däl, eciziñem ecizi. "Ben han değil, âcizin de âcizi." (BP:181).

Meniñ mazarımıñ başında daşam goymagın. Gerek däl. "Benim mezarımın başına taş bile koymayın. Gerekmez." (BP:177).

Mahmıda ol yeri hökmanam däldi.“Mahmıt için orası zorunlu da değildi." (S: 207).

- Govı edyäñ, oglum! Senden tamamam şeyledir. "-İyi ediyorsun, oğlum! Senden tam da bu

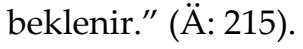

\section{i. Diğer Enklitiklerle Kullanımı}

Bazen de -am / -em biçimi üzerine anlamı daha da pekiştirmek için bir başka enklitik (ovnuk bölek) gelebilir. Bu durumda -am/-em'den sonra araya kısa bir çizgi (-) çekilir ve çizgiden sonra pekiştirici parçacık eklenir. Böylece iki pekiştirici unsur üst üste gelerek bir nevi pekiştirici yığılması ortaya çıkar. Ancak burada şunu da belirtmek gerekir ki -am/-em biçimi eklendiği eysem, diyseñem gibi bazı kelimelerde kalıplaşmış olarak kalır ve pekiştirme işlevi zayıfladığı için bir başka pekiştiriciye ihtiyaç duyulur. Sonuç olarak da eysem-de, diyseñem-ä şeklindeki kullanımlar ortaya çıkar.

Eysem-de bolsa, Çerkez öz beynisini hovsala aldırmadı. "Öyle de olsa, Çerkez endişelenmedi." (SE: 113).

- Diyseñem-ä, Sövder kaka, şu hayvanı̃̃ eñki agıpdır. "- Desenize, Sövder baba, bu hayvanın yavrusu düşmüş." (Ä: 68).

- Orazsoltan, menem-ä siziñ abrayl yeriñize şärikdirin. "- Orazsoltan, ben de sizin saygın yerinize ortağım." (İkbal: 28).

Iñ bärkisi, onuñ bilen tanşam-a däl. “En berideki, onunla tanıdık da değil.” (苂: 197).

\footnotetext{
8 Kişi ismi.

9 Yalancı eşdeğerliliğe sebep olabilecek bu durumlarda vurgu farkı vardır. Mesela yazılışları aynı olan: olam "Olam (boy ismi)" - olam < ol hem "o da"; başam "başparmak" - başam < baş hem "baş da, kişi de"; kelem "lahana, kelem" - kelem < kel hem "kel de"; üçem "1. üçüz (çocuk, yavru), 2. aşık kemiği ile oynanan bir oyun adı" - ü̧̈em < üçi hem "üçü de"; egrem "eğri, eğik, bükük" - egrem (bolsa) < egri hem "eğri de (olsa)" gibi örneklerdeki ilk sırada gösterilen kelimelerin sonunda bulunan -am/-em seslerinin bulunduğu son hece vurgulu iken, ikinci sırada gösterilen örneklerdeki "hem" bağlacının kısalmış ve ekleşmiş şekli olan -am/-em biçimi ise vurgusuzdur (Nurmuhammedov 2012: 105).
} 
- Äy, Motduk, ol don senin dıziñdanam-a bolcak däl! “- Ey, Motduk, o elbise senin dizinden bile girmez." (Gö: 21).

- Nazariñ bäş yaşar erkegem-ä gatı govı eken. “- Nazar'ın beş yaşındaki erkek çocuğu da oldukça iyiymiş." (Gö: 60).

- Novruzam-a okuva gidipdir. "- Novruz bile okula gidiyor." (Gö: 128).

- Hey, yaşı kesilen! Sen indi meni öldürcegem-ov! "-Hey, kahrolası! Sen şimdi beni öldüreceksin öyle mi he!"' (SE: 244).

- Senem-ä kolhozın işini edyän? “- Sen de mi kolhozun işini yapıyorsun?” (Gül: 48).

Edil şu vagt Derya ikimizem-ä özümiziñ erkinlikde, açık saçagıç başında oturanımıza dolı ınanıp bilemzok. "Tam o an Derya ile rahat rahat sofra başında oturmamıza ikimiz de inanamadık." (On: 5).

\section{j. Zarflar, Edatlar ve Bağlaçlarla Kullanımı}

Türkmen Türkçesindeki "hem" bağlacının -am/-em biçimindeki en tipik kullanımı zarflar, edatlar ve bağlaçlarla kullanımıdır. Oldukça yaygın olan bu kullanımları neticesinde özellikle cümle bağlayıcısı görevinde kalıplaşmış olarak âdeta yeni kelime türetir.

Aşağıda gösterilen yogsam, eysem gibi pek çok örneği olan kullanımlar artık kalıplaşmış olarak türemiş kelime biçimini almış ve sözlüklerde de madde başı olmuştur. Bu yogsam, eysem gibi kullanımların yeni kelime hüviyeti kazanması neticesinde, bu tür kelimelerin üzerine de tekrar -am/-em biçiminin gelmesiyle yogsamam gibi kullanımlar ortaya çıkmıştır.

Oldukça önemli olan bu tipik kullanımlar ve örnekleri aşağıda alfabetik sıraya göre verilmiştir ${ }^{10}$ :

ahıram

(< ahir hem) "sonra da, sonunda da"

Ahıram necis düşman merkini aldı. "Sonra da alçak düşman karşılığını aldı." (Gül: 331).

Ahıram on urup, özünden giderip taşladılar. "Sonra da ona vurup, kendilerinden uzaklaştırdılar." (Gül: 83).

Ahırınam yadap uklap galdı. "Sonunda da yorulup uyuya kaldı." (BP: 154).

ayratinam

(< ayratın hem) "özellikle de, bilhassa da"

Ol ogluniñ başarnıgına, zehinine, ayratınam tutan yerliligine guvanyardı. "O oğlunun başarısı,

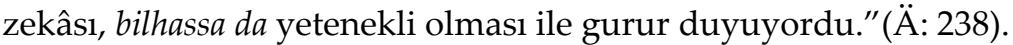

Ayratınam derya boylarında muña üns berdiler. "Özellikle de irmak boylarında buna dikkat ettiler." (苂: 183).

Ayratınam, ekcek tohumıniñ hiline üns bererdi. “Özellikle de, ekeceği tohumun türüne dikkat ederdi." (苂: 62).

\section{$\underline{\text { belkem }}$}

(< belki hem) "belki de"

- Onyança..,belkem, şu yıl uruş gutarar. "- O zamana kadar, belki de, o yıl savaş biter." (SE: 39).

10 Burada şunu ifade etmek gerekir ki "hem"den gelişen ve ekleşmiş “-am/-em” şeklini üzerine alan kelimelerin, ayratınam (BP: 78), ayratın hem (BP: 45) örneğinde olduğu gibi Türkmen Türkçesinde "hem" ile de kullanımına devam edilmektedir. Ayrıca, hasam yerine has hem kullanılabildiği gibi aynı manada has-da (S: 45) biçimleri de kullanılabilir. 
Arslan beg bolan bolsa ol, belkem, selcuk atlların güyci iki esse köp düşmanin üstüne gündiz sürmese-de sürmezdi. "Arslan bey olmuş olsa, belki de, Selçuklu atlarını gücü iki misli çok olan düşmanın üzerine gündüz sürmeyebilirdi." (S: 35$)$.

Belkem, egnindäki örtencäñ könelendir. "Belki de, sırtındaki örtü eskimiştir." (BP: 145).

Şu yerde, belkem onun dostları bardır. “Orada, belki de onun dostları vardır." (BP: 164).

\section{$\underline{\text { bilenem }}$}

(< bilen hem) "ile de, -la/-le de"

Mihmanlar mugallımlar bilenem, gızlar bilenem hoşlaşıp gitdiler. "Misafirler öğretmenlerle de, kızlarla da vedalaşıp gittiler." (Gö: 113).

Nazar pälvanlarıñ üçüsi bilenem duşuşdr. "Nazar pehlivanların üçüyle de karşılaştı." (Gö: 39).

Edil şunun yalı soraglar bilenem özümi horlap yörmezdim. "Bu tür sorularla da kendimi zorlamazdım." (BP: 116).

\section{birdenem}

(< birden hem) "birden bire, aniden"

Birdenem asman ähli suvunı döken yal, dünyäni suv-sil edip, çabga geldi... "Birden bire gökyüzü tüm suyunu boşaltır gibi, yeryüzünü sel aldı, sağanak boşandı..." (Ä: 9).

Birdenem Ayna bilen Gıtca yadına düşdi. "Aniden Ayna ile Gitca aklına geldi." (Gö: 85).

Birdenem ol düybünden nätanış ses eşitdi. "Birden bire o yanında tanıdık olmayan bir ses işitti." (BP: 154).

\section{dagam}

(< dagi hem) "dahi de, daha da, bile, da/de"

Adam dagam däl! “İnsan bile değil!" (Ä: 132).

Häzir "Onuñ yaşı togsandan dagam añırdadır" diyyärler. "Şu an "Onun yaşı doksandan daha

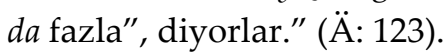

Begenç mugallım dagam bärden salam berip bardl. "Begenç öğretmen de öteden selam verip gitti." (Gö: 146).

\section{derrevem}

(< derrev hem) "derhal de, hemen de"

Şirin Aynaniñ köynegini biçdi, derrevem tikmäge oturdı. "Şirin Ayna'nın gömleğini kesti, hemen de dikmeye başladı." (Gö: 32).

\section{diyseñem/ diyseñizem}

(< diyseñ hem / diyseñiz hem) "desene, desen de, denilse de, desenize"

- Diyseñem, Doyduk ece, göz-ä biziñ sıgrımıza meñzeyär. "-Desene, Doyduk Hanım, göz de bizim sığırımıza benziyor." (SE: 206).

Oña bir vaka sebäp boldı diyseñem bolcak. "Buna bir olay sebep oldu desen de olur." (苂:42).

- Diyseñizem, bir yerde Añkar bar bolsa - şu şoldur! "-Desenize, bir yerde Añkar varsa, o budur!" (SE: 155).

\section{dogrudanam}

(< dogrudan hem) "gerçekten de, hakikaten de"

Arslan beg, dogrudanam, dagın arslanıdı. "Arslan bey, gerçekten de, dağın aslanıydı." (S: 61).

Dogrudanam, depäniñ yeñse yüzünde üstüni çäge basan iki sanı adam sudur mese-mälim gömüp 
durdı. "Hakikaten de, tepenin arka yüzünde üstündekileri kenara bırakmış iki kişi, siluet olarak görünen bir şeyi defnediyordu." (S: 7).

Dogrudanam, tutuş guburuñ üstünede ak gülün yaprakları seçelenip yatırdı. "Gerçekten de, tüm mezarın üstüne beyaz gül yaprakları saçılmıştı." (BP: 174).

\section{entegem / enteklerem}

(< entek hem) "şimdi de, şu anda da, hâlâ da; şimdilerde de"

Entegem, bu setirler şu garrıniñ hakıdasyna berk çümüp galıdır. "Şu anda da, o satırlar bu ihtiyarın hafızasına iyice kazınıp kalmıştı." (S: 225).

Entegem gözlerini yeñsesine dikip oturan Bilal hoca pessayca dillendi.. "Şimdi de arkaya doğru gözlerini diken Bilal bey yavaşça konuştu.." (S: 131).

Yağ çapan obanı̃̃ ahı-nalası entegem köşeşmändi. "Düşmanın yağmaladığı köyün feryadı hâlâ da dinmedi." (S: 35).

- Sen enteklerem meniñ düyşüme giryäñ. "- Sen şimdilerde de benim düşüme giriyorsun." (BP: 191).

\section{esasanam}

(< esasan hem) "esasen de, aslında da"

Esasanam, direktorı̃̃ göz öñ̈nde tutan zadı - bu çagalarıñ günde iñ bolmanda bir yola gızgin nahardan doymagıdı. "Aslında, müdürün göz önünde tuttuğu şey, bu çocukların günde en azından bir defa sıcak yemeğe doymasıydı." (Ä: 208).

\section{eysem}

(< eyle ise hem) "öyleyse, o hâlde"

- Men eysem bularsiz nähili mekdebe gideyin? “ - Ben o hâlde bunlarsız nasıl okula gideyim?" (SE: 22).

- Eysem, iki barmak kagıziñzam gısganyarsiñı-da? "- Öyleyse, iki parça kâğıdınızı da kıskaniyorsunuz galiba? (SE: 42).

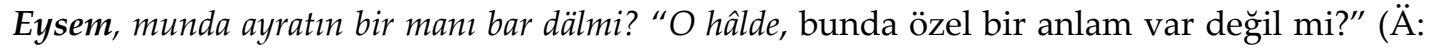
205).

\section{gaytam}

(< gayta hem) "aksine, tersine"

Seniñ gözden döken yaşlariña glyılcak yürek yokdur, gaytam, şatlanıp gülcekler köpdür.. "Senin gözünden akan yaşlara üzülecek yürek yoktur, aksine, mutlu olup gülecekler çoktur.." (İkbal: 262).

İndi barı: "Günäsini geç" diysem, ol bir cınlıdır, gaytam, odunı ölçeräyermikäm diyyän. "Şimdi gidip: "Affet” desem, o kızgındır, tersine, öfkesini arttırır mıyım acaba." (İkbal: 338).

Berdä kädisini bermeyärdi; gaytam, Berdiniñ dolı kädisini hernä özi äkidip, süydüni gazana boşadıp gelyärdi. "Berdi'ye kabağını vermiyordu; aksine, Berdi'nin dolu kabağını her nasılsa kendisi alıp, sütünü kazana boşaltıp geliyordu." (İkbal: 9).

Gaytam, onı hem atasınıñ ayıbını yaşırmak maksadı bilen... "Aksine, onu da babasının suçunu gizlemek maksadıyla..." (İkbal: 171).

\section{gezegem}

(< gezek hem) "defa da, kez de, kez bile" 
Bu gezegem şeyle boldr. "Bu defa da öyle oldu." (S: 237).

Ine, bu gezegem ol äpet kepcebaş bolup, Çagrı begiñ alnından çıkdı. "İşte, bu defa da o büyük çıban olarak, Çagrı beyin alnından çıktı." (S: 65).

Güllerimi bir görsedim, birce gezegem bolsa. "Çiçeklerimi bir görseydim, bir kez bile olsa." (BP: 171).

\section{ginansagam}

(< ginansak hem) "maalesef, üzülsek de"

- Yöne, gınansagam, Berdimuhamet mollumı bizden alcaklar. "-Ancak, maalesef, Berdimuhamet mollayı bizden alacaklar.“ (苂: 124).

\section{hakıkatdanam}

(< hakıkatdan hem) "hakikaten de, gerçekten de"

Hakıkatdanam, bu parhlllık nämäniñ neticesinde yüze çıkyarka?.. "Gerçekten de, acaba bu

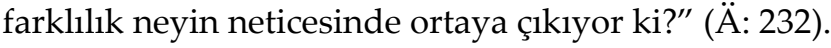

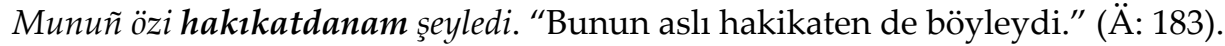

- Bä, hakıkatdanam, öz-ä Mapbak veli, munuñ kellesi kimkä? "- Aa, hakikaten de, kendisi Mapbak; ancak, bunun başı kim ki?" (SE: 211).

\section{hasam}

(< has hem) "oldukça, çok, çok da, gayet de"

Gelcegiñiz hasam acayıp bolar - diydi... "Geleceğiniz çok da mükemmel olur, dedi” (Ä: 156).

Baytalıñ halı hasam teñleşdi. "Kısrağın durumu oldukça kötüydü." (Ä: 24).

Şonda Ayna hasam gorkdr. "Bunun üzerine Ayna çok korktu." (Gö: 132).

Soltaniñ hovlası hasam artdı. "Sultanın endişesi oldukça arttı." (Gül: 38).

\section{haysam}

(< haysı hem) "hangisi, hangisi olursa olsun, her birisi de"

Her haysam hökman özüne baha beryärdi. "Her biri de mecburen kendisine değer veriyordu." (Gül: 168).

Haysam bolsa birini Annalı cana ber... - diyip, ulı ayalı yalbardı. "Büyük hanımı: -Hangisi olursa olsun birini Annalı'ya ver.., diye yalvardı." (Gö: 61).

\section{hälem}

(< häli hem) "şu an da, şimdi de, şimdi ise, hâlâ da"

Hâli hem bir pille ey adem oğhl "Şimdi ise öyle bir zaman ki ey insanoğlu" (Biray 1992: 114).

- Aydanıñı näme, sürüci hälem daşardamı? "-Ne diyorsunuz, şoför hâlâ da dişarıda mı?" (BP: $84)$.

\section{häzirem}

(< häzir hem) "şimdi de, şu anda da"

Inha, häzirem birnäçe vagt bäri at üstünde gezip yörşümdir. "İşte, şu anda da bir süreden beri at üstünde dolaşıyorum." (İkbal: 343).

Häzirem baylar menşeviklere kömek bermäge adam yıgnayarmış. "Şu anda da beyler azınlıklara yardım etmek için adam topluyormuş." (Gö: 37).

Şol agşamdan bäri ençeme yıllar geçdi. Sazandaniñ çalan acayıp mukamları häli-häzirem kalbında coşturıp dur. "O akşamdan beri çok yıllar geçti. Sanatçının çaldığ muhteşem ezgiler şimdi de 
kalbini coşturuyor." (BP: 131).

\section{$\underline{\text { henizem }}$}

(< heniz hem) "henüz, hâlâ da, hâlâ, daha"

Yatanlarin birnäçesinde henizem dirilik alamatı bardı. "Yatanların birkaçında hâlâ yaşam belirtisi vard1." (GB: 26).

Yöne ol içerik girmäge meyil etmedi, henizem diñmedik yagşa-da bakmadı. "Ancak o içeriye

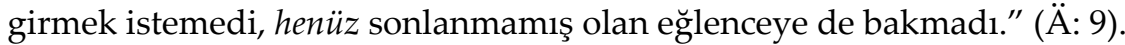

Nazariñ sag eli henizem yektayınıñ çep goltuginda... "Nazar'ın sağ eli hâlâ entarisinin sol koltuğunda..." (Gö: 17).

\section{$\underline{\text { heyem }}^{11}$}

( $<$ hey hem) "hemen, hem de, aslında, esasen"

Soltan yüz berende-de, heyem beydip yüzin düşäymek bolarm1... "Sultan yüz verdiğinde, hemen böyle surat asmak uygun olur mu..." (S: 282).

Heyem üstünden ötüp, ol adamı görmän gitmek bolarmı?! "Hem de önünden geçip, o adamı görmeden gidilir mi?!" (S: 180).

Heyem, selcuk begi gamçını̃̃ bir oynun görkezmän söze başlarmı diysene... "Aslında, Selçuklu beyi bir kamçı oyunu göstermeden söze başlar mı söylesene..."(S: 32).

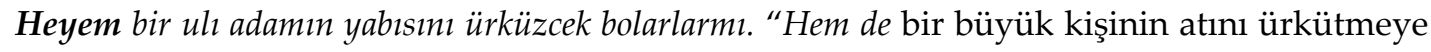
kalkarlar mı?" (Gül: 43).

\section{indem}

(< indi hem) "yeniden, tekrar, şimdi de, şimdi ise, artık, bir daha da, hâlâ da"

Olar muña ön-ä yitirip, indem tapan yalı bolup ihlas edyärdiler. "Onlar buna, önce kaybedip

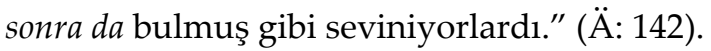

İndem, yör, yaşulınıñ yanına baralı, onı köp garaşdırmak gelşiksiz. "Şimdi ise, haydi, ihtiyarın

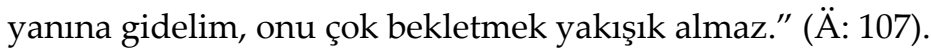

İndem uzak vagt bäri habar tutyan yok. "Hâlâ da uzun zamandan beri haber alan yok." (Ä: 27).

- Gülruh, seni men ilki görenimde söydüm. İndem men senden el çekmen. "- Gülruh, seni ilk görüşümde sevdim. Artık ben senden vazgeçmem." (BP: 179).

\section{megerem}

(< meger hem) "meğer, meğerse, ihtimal, galiba, muhtemelen, muhtemelen de"

Bagır hacıp, megerem, serkerdeleriñ birini öldüripdi. "Elçi Bagır, meğerse, askerlerden birini öldürmüş." (S: 170).

Megerem, bu yerleriñ ayratın özüne çekcilik güyci, gudratı bar bolmalı. "Galiba, buraların

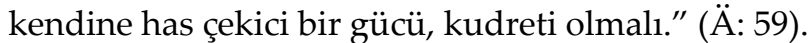

Megerem, öz sandıgını tanaydı öydyän. "Muhtemelen, kendi sandığını tanıdı." (S: 203).

Kempir, megerem, agır ukudadı. "İhtiyar kadın, muhtemelen, ağır bir uykudaydı." (S: 90).

\section{$\underline{\text { meselem }}$}

(< mesel hem// < mesela hem) "mesela, örneğin"

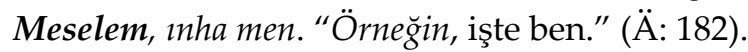

11 Türkmen Türkçesinde "heyem" kullanımı konusunda daha detaylı bilgi için Nergis BİRAY'ın, Türkmen Türkçesinde Kuvvetlendirme İşlevli Dil Birimleri: "hi, hi-de, hiy, hiy-de, hey, hey-de, heyem" başlıklı çalışmasına bakılabilir (Biray 2015b). 
- Meselem, onuñ gurluşı nähili? “- Mesela, onun yapısı nasıl?” (SE: 22).

\section{onsoñam}

(< onsoñ hem) "ondan sonra da, bundan sonra da, ayrıca da, üstelik de"

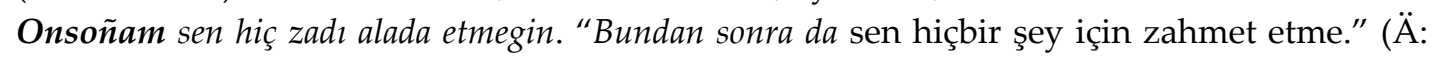
96).

Onsoñam her kime içiñem döküp bolanokdr. "Ayrıca da herkese içini dökemezsin.” (Ä: 59).

Onsoñam, galaniñ içinden oña iñ gerekli adam häkim däldi. "Üstelik de, kalenin içinde onun için en gerekli kişi hekim değildi." (S: 92).

\section{$\underline{\text { ovalam }}$}

(< oval hem) "evvel de, önce de"

Ovalam ol bagtıgara gizlariñ horlanıp yörşüne, öz doganlarıñ̃ elinden yer-suvun aldırıp... “Önce de o talihsiz kızların horlanmasına, kendi kardeşlerinin elinden yerlerini aldırıp..." (Gö: 77).

\section{$\underline{\text { ozalam }}$}

(< ozal hem) "çok önceden beri, önceden de, evvelden de"

Meniñ ozalam şu dünyäde azarım gıt däl, yüküm gatı agır. "Benim çok önceden beri bu dünyada sıkıntım az değil, yüküm çok ağır." (İkbal: 337).

- Men ozalam gice galdım. "-Ben önceden de geç kaldım." (Gül: 70).

Onuñ Aşgabatda yörite okuvo gutarıp, şu oba iberilendigini, ozalam öz obasında özbaşdak çaga okadandıgını yatlatdı. "Onun Aşgabat'ta özel okulu bitirip, bu köye gönderildiğini, evvelden de

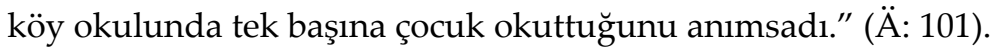

\section{$\underline{\text { sebäpdenem }}$}

(< sebäpden hem) "sebeple de, nedenle de"

Ol sebäpdenem men siziñ Bekmırat baylar bilen bir obadandıgiñzı bilmändirin. "Bu sebeple de ben sizin Bekmırat beyler ile aynı köyden olduğunuzu anlamamışım." (İkbal: 267).

Şol sebäpdenem ol dört-bäş yillap öz mekdebini yapmalı boldt. "Bu nedenle de o, dört beş y1l içinde kendi okulunu yapmaya karar verdi." (Ä: 62).

\section{$\underline{\text { soñam }}$}

(< soñ hem) "sonra da"

Ondan her haysı bir käse iyip, soñam çay içmäge başladılar. "Ondan herbiri bir kâse yiyip, sonra da çay içmeye başladılar." (Gö: 15).

Soñam agtıginin elinden tutup, öyüne dolandl. "Sonra da torununun elinden tutup, evine döndü." (苂: 35).

Izlar yola düşdi. Ol yolam buları demiryoluñ duralgasına alıp bardl, soñam yitdi. "İzler yola indi. O yol da bunları demiryolu durağına ulaştırdı, sonra da kayboldu." (Gö: 98).

\section{şeydibem}

(< şeyle edip hem) "böylece, böylece de, bu şekilde de"

Şeydibem, bu ulı goşun öz gabrını özi gazıpdır. "Böylece de, bu büyük ordu kendi mezarını kendisi kazmış." (S: 264).

Şeydibem, mekdebiñ yanında çagalar yaslisi hem-de bagı açıldı. "Böylece, okulun yanında çocuk

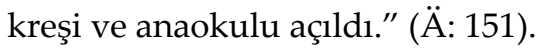

Şeydibem, iki yürek biri-birine ısnışdı. "Bu şekilde de, iki kalp birbirine ısındı." (BP: 140). 
Şeydibem, danalıga yetişdi. "Böylece, âlimlik derecesine ulaştı." (BP: 182).

\section{tasdanam}

( $<$ tasdan hem) "gerçekten de, hakikaten de, neredeyse, tam da"

Tasdan meniñ yüregimi yarıpdiñı! "Gerçekten de yüreğimi sızlattınız." (SE: 202).

Yigitler äpet çınarıñ kölegesinde toy gurup oturışlarına tasdanam cülgäniñ çetinden giren duşman goşunına üstüni basdırıpdılar. "Delikanlılar büyük çınarın gölgesinde eğlenirken neredeyse vadinin kıyısından gelen düşman askeri tarafından baskına uğratılacaklardı." (S: 109).

Ol tasdanam şu niyet bilen atını öñe debisgiläpdi. "Otam da bu niyetle atını öne sürdü." (S: 172).

\section{taydanam}

(< taydan hem) "açıdan da, bakımdan, yönden"

Ana, şo taydanam suv yalı akıp yatan çägeli uç-gıraksız çöl başlanyardı. "İşte, şu taraftan da su gibi akan kumlu uçsuz bucaksız çöl başlıyordu." (ت̈: 63).

\section{üçinem}

(< üçin hem) "için de, bu yüzden de"

Munuñ üçinem Hudaya şükür etmeli... "Bunun için de Allah'a şükretmeli..." (Ä: 194).

- Bu meniñ üçinem govı bolar. "- Bu benim için de iyi olur." (Ä: 133).

Şonuñ üçinem meni goyber! "Bu yüzden de beni bırak" (BP: 146).

Mertebä layık ınsan bolmak üçinem yola düşüpsin. "Mertebeye layık insan olmak için de yola düşmüşsün." (BP: 153).

\section{yalam}

(< yalı hem) "gibi, gibi de, sanki"

Dogrusını aytsam, hanım, selcerer yalam däl. "Doğrusunu söylersem, sultanım, fark edilir gibi de değil." (SE: 105).

Hemmesiniñ diyen yalam egin-eşigi sıpırılııdı. "Neredeyse hepsinin de elbiseleri çalınmıştı." (GB: 25).

\section{yogsam}

(< yok ise hem) "yoksa, değilse, aksi takdirde"

- Tüveleme diy, hanım, yogsam, birden gözün degäymesin? "-Maşallah de, sultanım, aksi takdirde, birden nazarın değiverir ha?" (SE: 9).

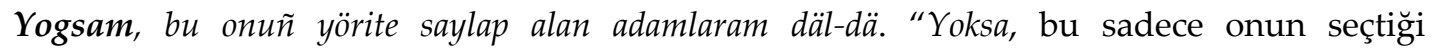

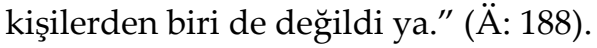

"Vah gurbum yetenok, yogsam-a yene bir ayal alaymal veli.." "Ah gücüm yetmiyor, yoksa başka bir hanım almalı ancak.." (Gö: 4).

\section{yogsamam}

(< yogsam hem) "yoksa da, değilse de, aksi takdirde de"

Yogsamam, traktordan çıkan adam-da Amandan arassa däldi, onuñ hem köyneginiñ egni yırtıkdı. "Yoksa, traktörden çıkan kişi de Aman'dan temiz değildi, onun da gömleğinin omzu yırtıktı." (SE: 18).

Yogsamam, şeyle bolmasañ, keramata eye bolaymak añsat däldir. "Aksi takdirde, böyle olmazsan, 
keramete sahip olmak kolay değildir." (İkbal: 287).

\section{Sonuç}

1. Türkmen Türkçesindeki "hem" sözcüğünün işlevleri ve kullanımı oldukça tipiktir. Türkmen Türkçesindeki tipik kullanımlarıyla dikkat çeken "hem" üzerine daha önce Salan (2011), Çevik Şavk (2003) gibi araştırmacılar tarafından özellikle işlevlerinin incelendiği müstakil çalışmalar yapılmıştır. Biray (2015a) da Türkmen Türkçesindeki "ovnuk bölekler" (pekiştiriciler) üzerine yaptığı genel çalışmada "hem" sözcüğünün de pekiştirme görevini örneklerle değerlendirmiştir.

Biz bu çalışmada, "hem" bağlacının işlevlerine değinmedik. Belirtilen çalışmalardan farklı olarak "hem" sözcügüunün "h-" ünsüzü düşmüş ve ekleşmiş "-am/-em" biçiminin kullanımı üzerinde durduk ve çalışmayı Türkmen Türkçesinde yazılmış eserlerden taranan "-am/-em" biçiminin kullanıldığı örneklerle sınırlandırdık.

Çalışmada, taranan metinlerden hareketle önce "-am/-em"in doğrudan isim kökleri ile kullanıldığı örnekler verildi. Sonra şahıs, dönüşlülü̈k ve işaret zamirlerinin yalın hâldeki ve hâl eki almış biçimleriyle "-am/-em" in kullanımı; çokluk eki ve iyelik eklerinden sonra "-am/-em" in kullanımı maddeler hâlinde örneklerle gösterildi. Aynı şekilde fiil çekim eklerinden ve fiilimsilerden sonra kullanımı üzerinde duruldu.

"Hem" sözcüğünün "-am/-em" biçiminde kullanılmasının sebep olduğu ünlü düşmesi ve tonlulaşma ses olayları örneklerle değerlendirildi. Yine "-am/-em" kullanımının ortaya çıkardığ 1 yalancı eşdeğerlilik konusu da verilen örneklerle ele alındı.

Son olarak çalışmada, "-am/-em" biçiminin edatlar, bağlaçlar ve zarflarla kullanımı ve bunun neticesinde kuvvetlendirme yoluyla yeni bir anlam boyutu kazandırdığı ve bu tür kullanımların artık sözlüklerde de madde başı olarak yer almaya başlandığı hususu belirtildi. Türkmen Türkçesinde yaygın olarak kullanılan bu türden kelimeler ve kullanım örnekleri maddeler hâlinde gösterildi.

2. Türkmen Türkçesinde “hem” sözcüğü, Salan (2011) ve Biray (2015a)'ın çalışmalarında da belirlediği üzere bağlaç ve pekiştirici görevinde kullanılır. Günümüz Türkmen Türkçesi yazı dilinde "hem" biçiminde ve "h-" ünlüsü düşürülmüş ve damak uyumuna bağlanmış "-am/-em" biçiminde ikili kullanımı mevcuttur.

3. "Hem" sözcüğünün "h-" ünsüzü düşmüş "-am/-em” biçimindeki kullanımı aslında konuşma diline has bir özellik iken, yazı dilinde kullanılmaması için mücadele edilse de, artık son dönemlerde yazı diline de geçmiş ve gramatikalleşmiştir.

4. "Hem" sözcüğü bağlama edatı görevinde bağlanacağı unsurdan önce geldiğinde her zaman "hem" biçiminde kullanılırken (hem Mırat hem ecesi), pekiştirici görevinde bağlanacağ unsurdan sonra geldiğinde ise "hem" (Mirat hem ecesi hem) ya da "-am/-em" (Miradam, ecesem) biçiminde iki şekilde de kullanılabilir.

Her ne kadar "hem" ya da "-am/-em" biçiminin kullanımı ile ilgili düzenli bir sistem olmasa da, bağlanacağı unsurdan sonra geldiğinde "hem" yerine çoğunlukla ekleşmiş ve damak uyumuna girmiş "-am/-em" biçimi tercih edilir. Bu durumda da sonuna geldiği unsura bitişik yazılır.

5. "Hem" sözcüğünün "h-" ünsüzü düşürülerek ekleşen "-am/-em" biçimi başlangıçta konuşma dilinde ortaya çıkmış ve sonradan yazı dilinde de kullanılmaya başlanmış bir biçim olsa da, Türkmen Türkçesi yazı dilinde bu kullanım günümüzde gittikçe yaygınlaşmıştır.

6. "Hem"den gelişmiş olan "-am/-em" biçimi, isim ve isim türünden kelimelerle çok sık kullanılır. Özellikle şahıs ve dönüşlülük zamirleri ve görevli kelimelerden edat ve bağlaçlarla kullanımı yaygındır. Ayrıca, isim çekim eklerinden ve fiil çekim eklerinden sonra da yaygın 
olarak kullanılır. Çalışmada bu tipik kullanımlar eserlerden taranan birçok örnekle detaylı olarak gösterilmiştir.

Türkmen Türkçesinde, özellikle pekiştirici görevinde, "hem" yerine "-am/-em" kullanımı gittikçe yaygınlaşmaktadır. Mesela, men, sen şahıs zamirleri ile "hem"in kullanımında men hem, sen hem şeklinde kullanmak yerine artık menem, senem kullanımları tercih edilir hâle gelmiştir.

7. "Hem"in "h-" ünsüzü düşmüş ve ekleşmiş "-am/-em" biçimi ünsüzle biten tabanlara doğrudan gelebilir. Ancak, ünlü ile biten tabanlardan sadece dar ünlülerden sonra gelir, geniş ünlülerden sonra gelmez.

Taranan eserlerden tespit edilen "hem"in "h-" ünsüzü düşmüş ve ekleşmiş "-am/-em" biçimi ile ilgili örnekler "-am/-em" biçiminin geniş ünlü ile biten kök ya da çekimli hâldeki kelimelerden sonra gelmediğini göstermektedir. Diğer bir değişle "-am/-em" biçimi sadece dar ünlü ile biten kök ya da çekimli kelimelerden sonra gelir.

8. Türkmen Türkçesinde ünlü ile biten bir tabana bir ünlü ek (mesela $+a /+e$ yönelme hâli eki) veya ünlü ile başlayan bir ek (mesela -Ip zarf-fiil eki) geldiğinde, kelime tabanındaki ünlü ile ekin ünlüsü önce diftong oluşturur, sonra da ikincil uzunluklar ortaya çıkartır. Örneğin yönelme hâli eki ünlü ile biten bir isme geldiğinde kiçi-e > kiçä (kiçä:) şeklinde; zarf-fiil eki ünlü ile biten bir fiile geldiğinde işle-ip > işläp (işlä:p) şeklinde ikincil ünlü uzamasına sebep olur.

Ancak konumuz olan "hem" in "h-" ünsüzü düşmüş ve ekleşmiş "-am/-em” biçimi ünlü ile biten tabanlara geldiğinde ikincil bir telafi uzunluğuna sebep olmaz, diğer bir ifadeyle ünlüler birleşmez. Örneğin yukarıdaki kiçi "küçük" kelimesine "-am/-em" biçimi geldiğinde: kiçi+em (< kiçi hem) > kiçem şeklinde ünlü birleşmesi olmadan kullanılır. "Hem” sözcügüünden ekleşen "am/-em" biçiminin kullanımında ikincil bir uzunluk ortaya çıkmayıp eklendiği tabanın dar ünlüsünün düşmesi Türkmen Türkçesinde "-am/-em" in kullanımı ile ilgili oldukça tipik bir özelliktir.

9. "Hem" yerine "-am/-em" biçiminin kullanımını ünlü düşmesi ve tonlulaşma ses olaylarına sebep olur. Yukarıda "-am/-em" biçimin sadece dar ünlülerden sonra geldiği ve ünlü birleşmesine sebep olmadığı belirtilmişti. Üzerine geldiği dar ünlü Türkmen Türkçesinde düşer. Ünlü düşmelerinden, yükleme hâli ekinin (senem < seni hem) ve iyelik ekinin (yerem < yeri hem) düşmesi oldukça tipiktir.

Aynı şekilde vurgusuz orta hece ünlüsünün ( $\operatorname{ggzam}<a g \imath \mathrm{hem})$ ve üzerine geldiği kelimenin son ünlüsünün (kiçem < kiçi hem) düşmesine de sebep olur.

Aitlik ekinin ünlüsünün (meniñkem < meniñ ki hem) ve fiil çekim eklerinden görülen geçmiş zaman ekinin (çekdem < çekdi hem), gereklilik kip ekinin (bilmelem < bilmeli hem) son ünlüsünün düşmesi de diğer tipik ünlü düşmelerindendir.

Tonsuz ünsüzlerden sonra "-am/-em" biçiminin gelmesi tonlulaşmaya da sebep olur: köynegem < köynek hem; kitabam < kitap hem; yigidem < yigit hem gibi.

10. Türkmen Türkçesinde "-am/-em" biçiminin kullanımı yalancı eşdeğerliliklere de sebep olur. Örneğin senem: 1. senem "put; sevgili"; 2. senem (< sen hem) "sen de"; 3. senem (< seni hem) "seni de" biçiminde üç farklı anlama gelecek şekilde kullanılabilir ve hangi anlamda kullanıldığı cümlenin bağlamından anlaşılır.

Aynı şekilde balam kullanımı hem bala "evlat, çocuk" kelimesinin iyelik eki almış (bala+m) şekli hem de bal kelimesinin "hem" sözcüğünden ekleşmiş “-am/-em" biçimini almış (balam < bal hem) şekli olabilir.

11. "-am/-em" biçimi Türkmen Türkçesinde zarflar, edatlar ve bağlaçlardan sonra anlamı pekiştirme fonksiyonunda yaygın olarak kullanılır. Bu kullanımlarda sonuna geldiği kelime ile âdeta kalıplaşır ve yeni bir zarf ya da yeni bir edat veya bağlaç gibi kullanılmaya başlar. 
Örneğin yogsa kelimesi Türkmen Türkçesinde üzerine “-am/-em” biçimini alarak yogsam (< yogsa hem) "değilse, yoksa" şeklinde de kullanılır ve sözlüklerde de madde başı olarak yer alır. Böylece yogsam kullanımının türemiş yeni bir kelime hüviyeti kazanması sonucunda üzerine tekrar "-am/-em" biçimini alabilir ve yogsamam (< yogsam hem) "değilse de, aksi takdirde de" kullanımı ortaya çıkar.

12. Son olarak "hem" sözcüğünün "h-" sesinin düşmesi sonucu ortaya çıkan ve tipik kullanım özellikleri taşıyan "-am/-em" biçiminin Türkmen Türkçesi üzerine yapılacak araştırmalarda ve aynı zamanda öğrenimi ve öğretiminde dikkat edilmesi gereken önemli hususlardan biri olduğu belirtilebilir. 


\section{Taranan Eserler}

SE: $\quad$ KERBABAYEV, BERDİ (1992), Saylanan Eserler, Hekayalar, Povestler ve Folklor Orta Ulı ve Yaşlı Mektep Okuvçıları Üçin, Aşgabat: “Magarıf” Neşriyatı.

Gö: $\quad$ AŞIR, Çarı (1986), Göreş, Aşgabat: “Türkmenistan” Neşiryatı.

S: $\quad$ MÜLKIYYEV, Cumageldi (2010), Selcuklar, Aşgabat: Türkmen Dövlet Neşirtyat Gullug1.

BP: $\quad$ GARACAYEV, Cumanazar (2013), Bagtlı Pursatlar, Aşgabat: Ilım Neşriyatı

Ä: $\quad$ BERDIMUHAMEDOV, Gurbangulı (2011), Älem İçre At Gezer, Aşgabat: Türkmen Dövlet, Neşiryat Gullugı.

Gül: HOCAGELDIYYV, Nargilıç (1974), Gülle Degen Sümbüller, Aşgabat: “Türkmenistan" Neşriyatı.

İkbal: DERYAYEV, Hıdır (1981), İkbal, Roman (Eserler Yıgındısı Birinci Tom), Aşgabat: "Türkmenistan Neşriyatı".

GB: ÖVEZBAYEV, Seyitmırat (1991), Gönübek (Gökdepe söveşine gatnaşan türkmeniñ gürrüñi), Aşgabat.

On: $\quad$ KAROV, Durdı (1994), On Yıl Türmede, İkinci Kitap, “Turan-1”, Aşgabat: Ilım.

PE: $\quad$ GOVŞUDOV, Ata (1989), Perman, Aşgabat: “Türkmenistan” Neşiryaty.

\section{Kaynakça}

BİRAY, Himmet (1992), Mahtumkulu Divanı, Ankara: Kültür Bakanlığı Yayınları.

BİRAY, Nergis (2015a), "Türkmen Türkçesinde Ovnuk Bölekler”, Teke, Uluslararası Türkçe Edebiyat Kültür Eğitim Dergisi Sayı: 4/3 2015 s. 955-994.

BİRAY, Nergis (2015b), “Türkmen Türkçesinde Kuvvetlendirme İşlevli Dil Birimleri: "hi, hi-de, hiy, hiy-de, hey, hey-de, heyem", Diyalektolog, Kış 2015, Sayı 11, sy. 1-13.

BORCAKOV, A. vd. (2000), Türkmen Diliniñ Grammatikasy: Morfologiya. Aşkabat: Ruh Neşriyat (Türk Dil Kurumu Armağanı).

CLARK, Lary (1998), Turkmen Reference Grammar, Harrassovitz Verlag, Viesbaden.

ÇELIKK ŞAVK, Ülkü (2003), “Türkmence'de Hem (-em/-am) Üzerine”, Arayışlar, İnsan Bilimleri Araştırmaları, sayı 9-10, Isparta.

GELDIMIRADOV, A. (1983), Türkmen Edebi Dilinde Variantlaşma, Aşgabat: Ilım Neşriyatı.

KARA, Mehmet (2007), "Türkmen Türkçesi", Türk Lehçeleri Grameri (Editör: Ahmet Bican ERCILASUN), Ankara: Akçă̆ Yayınları.

KARTALLIOĞLU, Yavuz ve YILDIRIM, Hüseyin (2007), “Azerbaycan Türkçesi”, Türk Lehçeleri Grameri (Editör: Ahmet Bican ERCİLASUN), Ankara: Akçă̆ Yayınları.

NURMUHAMMEDOV, Amanmuhammet (2012), Türkmen Dilinde Söz Basımı, Aşgabat: Ilım Neşriyat.

ÖZKAN, Nevzat (2007), “Gagavuz Türkçesi”, Türk Lehçeleri Grameri (Editör: Ahmet Bican ERCILASUN), Ankara: Akçağ Yayınları.

PİRLIYEV, G. vd. (1996), Türkmen Dili, Aşgabat: “Magarıf”. Neşriyatı

SALAN, Erkan (2011), “Türkmen Türkçesi ile Türkiye Türkçesinde “hem” Sözcügünün İşlev Bakımından Karşılaştırılması", Turkish Studies, Volume 6/11 Vinter, s. 1670-1686.

TS (2016), Türkmen Diliniñ Düşündirişli Sözlügi II Tom, Aşgabat: Türkmen Devlet Neşriyatı.

YILDIRIM, Hüseyin (2008), Zelilî Divanı (Metin-Aktarma-Gramer İncelemesi), Basılmamış Doktora Tezi, Gazi Üniversitesi Sosyal Bilimler Enstitüsü, Ankara. 